23. Ved, M. Catalytic properties of binary and ternary alloys based on silver [Text] / M. Ved, M. Glushkova, N. Sakhnenko // Functional Materials. - 2013. - Vol. 20, № 1. - P. 87-91. doi: $10.15407 / \mathrm{fm} 20.01 .087$

24. Yar-Mukhamedova, G. Iron binary and ternary coatings with molybdenum and tungsten [Text] / G. Yar-Mukhamedova, M. Ved, N. Sakhnenko, A. Karakurkchi, I. Yermolenko // Applied Surface Science. - 2016. - Vol. 383. - P. 346-352. doi:10.1016/ j.apsusc.2016.04.046

25. Karakurkchi, A. V. Functional properties of multicomponent galvanic alloys of iron with molybdenum and tungsten [Text] / A. V. Karakurkchi, M. V. Ved', N. D. Sakhnenko, I. Yu. Yermolenko, S. I. Zyubanova, Z. I. Kolupayeva // Functional materials. 2015. - Vol. 22, № 2. - P. 181-187. doi:10.15407/fm22.02.181

26. Ved', M. V. Functional Properties of $\mathrm{Fe}-\mathrm{Mo}$ and $\mathrm{Fe}-\mathrm{Mo}-\mathrm{W}$ Galvanic Alloys [Text] / M. V. Ved', M. D. Sakhnenko, H. V. Karakurkchi, I. Yu. Ermolenko, L. P. Fomina // Materials Science. 2016. - Vol. 51, № 5. - P. 701-710. doi:10.1007/s11003-016-9893-5

27. Сахненко, Н. Д. Электроосаждение покрытий сплавом железомолибден [Текст] / Н. Д. Сахненко, М. В. Ведь, А. В. Каракуркчи // Вопросы химии и химической технологии. - 2013. № 4 - C. 178-182.

28. Ved', M. V. Electroplating and functional properties of Fe-Mo and Fe-Mo-W coatings [Text] / M. V. Ved', N. D. Sakhnenko, A. V. Karakurkchi, I. Yu. Yermolenko // Issues of Chemistry and Chemical Technology. - 2015. - № 5-6 (98). - P. 53-60.

\section{ДОСЛІДЖЕННЯ ОСОБЛИВОСТЕЙ ФОРМУВАННЯ ТА ВЛАСТИВОСТЕЙ ПОКРИТТІВ ЗАЛІЗА З ТУГОПЛАВКИМИ МЕТАЛАМИ НА СІРОМУ ЧАВУНI СЧ18}

Досліджено особливості електроосадження багатокомпонентних покриттів заліза з тугоплавкими металами (молібденом і вольфрамом) із цитратних електролітів заліза(III) на підкладках із сірого чавуну. Показано, що вміст легуючих компонентів, їх розподіл по поверхні та морфологія покриттів залежать від режиму нанесення. Встановлено, що функціональні властивості багатокомпонентних сплавів заліза (корозійна стійкість, мікротвердість, зносостійкість) перевищують показники підкладки та визначаються складом тонкоплівкових матеріалів.

Ключові слова: покриття заліза, сірий чавун, тугоплавкі метали, електроосадження, електролітичний сплав, корозійна стійкість.

Каракуркии Анна Владимировна, кандидат технических наук, начальник научно-исследовательской лаборатории, Национальный технический университет «Харьковский политехнический институт», Украина, e-mail: anyutikukr@gmail.com, ORCID: http://orcid.org/0000-0002-1287-3859

\section{Mel'nick V., Rhuzinska L., Forostyanko V.}

\title{
CONSTRUCTION OF MATHEMATICAL MODEL OF DISSOLUTION PROCESS OF SOLIDS UNDER ACTION OF ULTRASOUND
}

Показано результати напівнатурних випробувань при розчиненні твердих речовин в рідких розчинниках в умовах діі ультразвуку в рідкому середовищі та запропонована математична модель процесу. Виявлено появу знакозмінного тиску, течії, кавітації, що сприяють інтенсифікації процесів масопереносу. Доведено, що швидкість розчинення твердих речовин залежить від інтенсивності, частоти та амплітуди ультразвукових коливань.

ключові слова: розчинення, ультразвук, дифузія, масоперенос, інтенсифікація, кавітація, бульбашки, тверда гранула, швидкість.

\section{Introduction}

Dissolution process of solids in liquid solvents are widely used in biotechnology and pharmaceutical industries to prepare nutrient medium components, semi-finished products and auxiliary products at different stages of technological production of finished products.

Dissolution is considered as unauthorized diffusion kinematic process that occurs in the collision of dissolved material and solvent [1]. Dissolution of insoluble substances in liquids is very long, labor-intensive and slow process [2,3]

Analysis of dissolution process of solids in liquid solvents can provide the following steps $[4,5]$ :

1. Contact of solid surface with a solvent, which is accompanied by wetting, adsorption and solvent penetration in the micropores of the particles of solids.
2. Solvent molecules interact with layers of material at the phase boundary. Solvation of molecules or ions and their separation from the phase boundary is observed during this process.

3. Solvated molecules and ions pass into the liquid phase.

4. Equalization of the solute concentration in all layers of solvent.

Duration of dissolution process generally depends on the rate of the individual stages. The second and third stages are determined mainly by chemical processes, and the first and fourth - by diffusion processes (mass transfer process). In practice, dissolution rate depends mainly on the rate of mass transfer processes during dissolution process.

The various methods are used to intensify the dissolution process:

1. Direct flow.

2. Dissolution in suspended state of the particles. 
3. Dissolution at rotary motion of the liquid.

4. Dissolution in a changing direction and flow rate of the liquid associated with inertia of the particles, such as:

- Dissolution using mechanical vibrations.

- Dissolution using electric spark in the liquid.

- Dissolution of the flow rate changes periodically.

One of the promising areas for intensification of dissolution process of solids in the liquid solvents are use of acoustic vibrations, or, as they are traditionally called, ultrasonic vibrations [6]. Ultrasonic vibrations have an influence on dissolution process through the frequency, intensity, velocity of acoustic vibrations, and promote the mass transfer process due to the emergence of cavitation and acoustic flows in the liquid. The choice of acoustic device for dissolution process of solids in liquid solvents and modes of its operation necessitates the study of the influence of ultrasound treatment factors by developing a mathematical model of the process $[7,8]$.

\section{The object of research and its technological audit}

The object of research is an influence of the ultrasound beam on the process, dissolution of solids in liquid solvents and mass transfer of frequency, intensity, velocity of acoustic vibrations, cavitation and acoustic flows.

Dissolution process is considered for granules of soluble inorganic compounds, such as superphosphate and calcium carbonate, magnesium sulfate, calcium.

Disadvantages include long duration of dissolution process, which only partially enhanced by mechanical stirring. And for dissolution, in terms of ultrasound, intensification is achieved only in conditions of the flows, cavitation, but also by changing the properties of water as a solvent.

\section{The aim and objectives of research}

The aim of research is the development of a mathematical model of dissolution process of solids in liquid solvents under ultrasonic vibrations and determination of influence of frequency, intensity, acoustic vibrations rate, cavitation and acoustic flows on mass transfer process. This will help develop a methodology for calculating process equipment for dissolution of solids in liquid solvents in terms of the source of ultrasonic irradiation.

To achieve this aim it is necessary to perform the following tasks:

1. Analyze the dissolution process of solids in liquid solvents in terms of ultrasound.

2. Find out what determines the dissolution rate of the granules in conditions of acoustic turbulence flow.

3 . Find out what determines the dissolution rate of the granules in conditions of cavitation.

\section{Research of existing solutions of the problem}

There are studies of the effectiveness of ultrasonic irradiation frequency of $20 \mathrm{kHz}$ to increase the mass transfer coefficient and dissolution of benzoic acid in water or in $24 \%$ aqueous solution of glycerol [9]. In [10] the influence of ultrasonic irradiation is studied at a frequency of $19 \mathrm{kHz}$ and power of $475 \mathrm{~W}$ on solid dispersion and increase of the solubility of insoluble drugs in water. Reduction of ferric iron $\left(\mathrm{Fe}^{3+}\right.$ to ferric iron $\left(\mathrm{Fe}^{2+}\right)$ at zinc production is carried out using ultrasound. It is proved that mass transfer coefficient is greatly increased under the influence of ultrasound in any media [11]. Salt secretion from building materials under ultrasonic irradiation is analyzed in [12].

Method using vibration machine for salt extraction in the water (72 hours) and the proposed method using ultrasound, which reduces this period to less than 1 hour are compared. Research of dissolution of cellulose components in ionic liquids under the influence of ultrasound is carried out in [13]. Ultrasound power of $30 \mathrm{~W}$ reduced dissolution time from 60 minutes to 20 minutes. An intensification of oil extraction process from process oilseeds under the influence of ultrasound is carried out in [14]. Solubility of oil in the solvent is increased using ultrasound. Ultrasound treatment of cellulose and starch is analyzed in [15]. It violates their structure to improve fermentation hydrolysis. According to data obtained in the work it is shown that fermentation is better and the final yield increases significantly.

Analysis of the literature shows that the generalized equation that describes the dissolution process for high rate of phase-boundary transition has the form [16]:

$$
-\frac{d m}{d \tau}=\beta F \cdot\left(c^{*}-c\right),
$$

where $m$ - weight of dissolved granule; $F$ - surface of the granule; $\beta$ - mass transfer coefficient; $c^{*}$ and $c-$ concentrations of dissolved material in saturation state and in the solution, accordingly.

Mass transfer coefficient $\beta$ depends on the thickness of the diffusion boundary layer, which in turn depends on the hydrodynamic boundary layer of liquid velocity at the surface of dissolved granule.

In general, the mass transfer coefficient is determined by the equation:

$$
\beta=\frac{D}{\delta} .
$$

Criterion equations are used to determine the mass transfer coefficient. They take into account the properties of the solvent and hydrodynamic conditions during the process.

The next equation for dissolution processes of spherical granules under free convection is proposed in the literature [9]:

$$
N u^{*}=0,6\left(G r \cdot \operatorname{Pr}^{*}\right)^{0,25},
$$

where:

- Grashof number:

$G r=\frac{g d^{3}}{v^{2}} \frac{\Delta \rho}{\rho}$

- Diffusion Prandtl number:

$\operatorname{Pr}^{*}=\frac{v}{D}$

- Diffusion Nusselt number:

$N u^{*}=\frac{\beta d}{D}$. 
Ultrasonic vibrations can intensify the mass transfer process due to the flow occurrence in stationary liquid and destruction of boundary layer near the surface of the dissolved granule.

Analysis of ultrasound influence on the liquid shows that periodical displacement of the particles and constant flows with different character and origin are observed in the acoustic flow.

Such flows are occurred in real viscous media as in free field and around the obstructions. Particular interest in terms of the dissolution process has a character of interaction of viscous liquid with solid walls of the obstructions due to which tangential displacement rate of the particles in the medium (liquid layers) adjacent to the wall (obstruction surface) should be converted to zero. It is assumed that the thickness of the layer, in which this interaction occurs, has the order of the penetration depth of the shear waves in the liquid and the absorption coefficient of shear waves in the liquid $\alpha_{c}$ is determined by the equation [17]:

$$
\alpha_{c}=\left[\frac{W \rho_{0}}{2 \eta_{c}}\right]^{1 / 2} .
$$

The distance at which the wave damps that is the depth of its penetration is estimated by relation [17]:

$$
\Delta \approx\left[12 \eta_{c} / W \rho_{0}\right]^{1 / 2} .
$$

Turbulent flows that occur in a layer of $\Delta$ thickness are observed mainly at low audio frequencies.

Ultrasonic fields are characterized by the flows that occur in a free ultrasound beam with high intensity, implemented in the ultrasonic frequency range.

Flow is caused by irradiation pressure along the ultrasonic beam associated with the power absorption of ultrasonic waves by the medium.

Irradiation force on liquid volume unit (absorbing medium) along the direction of ultrasonic waves is determined by the formula [17]:

$$
F=\frac{d \omega}{d x}
$$

This force causes a stationary flow, which rate can be calculated on the basis of hydrodynamic equations of motion for an ideal fluid. Let's denote stationary acoustic flow rate as $V_{0}$. Then the equation of motion for an ideal fluid [17]:

$$
-\frac{d \omega}{d x}=\rho \frac{d V_{0}}{d t}+\rho V_{0} \frac{d V_{0}}{d x} .
$$

For fluid that is not compressed if:

$$
\rho=\rho_{0}=\text { const }, \quad \frac{d V_{0}}{d t}=0 .
$$

The equation of motion takes the form:

$$
-\frac{d \bar{\omega}}{d x}=\rho_{0} V_{0} \frac{d V_{0}}{d x} .
$$

Let's integrate equation within: $x=0$ - emitter location; $x$ - current location.

Taking into account that at $x=0-$ ultrasonic wind rate is 0 , let's write energy conservation equation [2]:

$$
\frac{\rho_{0} V_{0}^{2}(x)}{2}=\bar{\omega}(0)-\bar{\omega}(x) .
$$

Stationary acoustic flow rate on the basis of obtained equation is written as [17]:

$$
V_{0}=\Delta P R_{t}^{2}(4 \eta \cdot x),
$$

where $R_{t}$ - radius of the beam tube; $\Delta P$ - pressure difference in points at a distance $x$, which is determined by the equation:

$$
\Delta P=\bar{\omega}(0)-\omega(x)=\bar{\omega}(0)\left[1-\omega(0) \cdot e^{-2 \alpha_{0} x}\right] .
$$

Given the connection of energy density and ultrasound intensity [17]:

$$
V_{0}=I_{0} R_{\mathrm{rp}}^{2} \alpha_{0}\left(2 \eta_{c} C_{0}\right),
$$

where $I_{0}$ - intensity of the ultrasound beam or ultrasound source; $\alpha_{0}$ - amplitude absorption coefficient of ultrasound; $C_{0}$ - speed of sound in the medium.

Ultrasonic influence are intensified mass transfer processes in the boundary layer of granules at low frequencies and promoted mixing and averaging of dissolved material concentration in the liquid at high frequencies.

\section{Methods of research}

The basis of the test bench is submersible unit of ultrasonic transducer УЗП-6-1 (Ukraine), which forms the ultrasound beam of $42 \mathrm{kHz}$ frequency with a flat front.

Cylindrical plate with liquid is placed inside the waterfilled body of the test bench.

Research of dissolution process is carried out for organic salts in the field of ultrasonic cavitation on the test bench (Fig. 1, 2).

The experimental setup in Fig. 1 consists of ultrasonic generator 1 and ultrasonic transducer 2. The ultrasonic transducer is submersible unit that is mounted in a container 3 with a working fluid. Flask 5 is mounted on a support 4 (volume $\mathrm{V}=120 \mathrm{ml}$ ). Thermocouple 6 is measured the temperature.

The source of ultrasonic vibrations is low ultrasonic generator 1 (Fig. 2,a) with irradiation frequency of ultrasonic vibrations $36 \mathrm{kHz}$, power $300 \mathrm{~W}$ and intensity of ultrasonic vibrations $1,65 \mathrm{~W} / \mathrm{cm}^{3}$.

Ultrasonic transducer 2 (submersible unit) (Fig. 2, b) is made of stainless steel and consists of 6 ultrasonic transducers that convert electrical energy into ultrasonic vibrations. Submersible unit is connected to the ultrasonic generator 1 and installed in container 3 in a way that it is completely covered by the working fluid. This is due to the fact that ultrasonic vibrations are used in the processes associated with liquid reagents states, because only they have a specific process - ultrasonic cavitation, providing maximum power influence on different matters. 


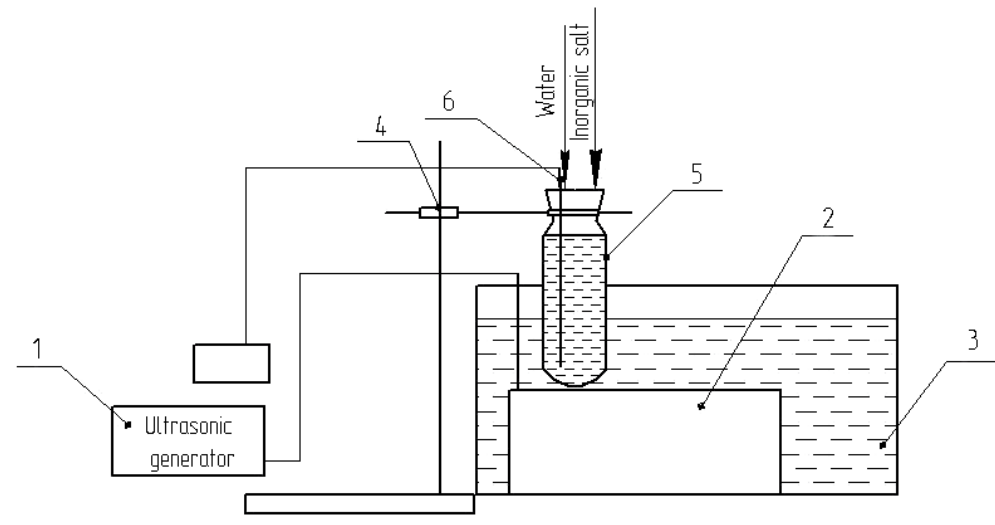

Fig. 1. Schematic diagram of the test bench: 1 - ultrasonic generator; 2 - ultrasonic transducer; 3 - container; 4 - support; 5 - flask; 6 - thermocouple

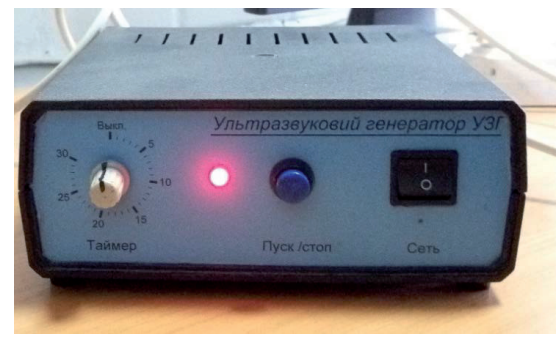

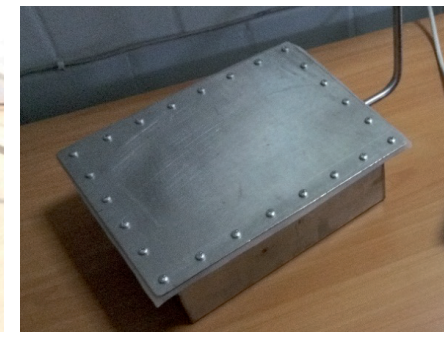

$b$
Fig. 2. Ultrasound device photo: $a$ - ultrasonic generator; $b$ - ultrasound transducer 2 (submersible unit)

$100 \mathrm{ml}$ of water is poured in the flask 5 . Fill 1,3 , $5,10,15 \mathrm{mg}$ of inorganic salt, such as superphosphate. Switch the ultrasonic generator 1. Cavitation is occurred under the influence of ultrasonic vibrations in liquid, and as a result, dissolution of salts is accelerated and heatmass transfer process is intensified. During experimental studies determine the time during which there is dissolution of salt and change of solution temperature in the test volume.

\section{Research results}

Let's consider the process of convective diffusion in terms of acoustic influence and occurrence of acoustic flows and microflows for dissolution of solids in the water. Solid particles have spherical granule shape. It is established that in acoustic field, acoustic flows (turbulent stationary flows) occur both in free space (in a non-uniform acoustic field), and close to various kinds of obstructions.

Analysis of mass transfer processes in terms of ultrasound treatment shows that the concentration equalization of dissolved material in the liquid is intensified under the influence of acoustic flows and microflows. In the boundary layer, near granules, reduction of mass transfer resistance is due to the occurrence of cavitation bubbles.

As shown in [18], $10^{2} \ldots 10^{3}$ items $/ \mathrm{cm}^{3}$ of cavitation bubbles are formed at advanced acoustic cavitation in water, and the average distance between the bubbles is defined by:

$$
r_{0}=\frac{1}{n^{1 / 3}}=10^{-3} \ldots 10^{-1} .
$$

Reynolds number is within $\operatorname{Re}=0,1 \ldots 1$. So in case of cavitation, increase of the dissolution rate of fine particles is explained by periodic variable, in magnitude and direction of flows around the cavitation bubble.

Dissolution rate of solid granules in water in the face of acoustic flows depends on the ratio of the granules and the maximum turbulence scale $\lambda_{0}$, defined by the formula [18]:

$$
\lambda_{0}=\frac{b^{3 / 4}}{\rho^{3 / 4} \varepsilon^{1 / 4}},
$$

where $b$ - acoustic viscosity that takes into account viscous energy losses and losses that are inherent to vibration media.

Acoustic viscosity is calculated using the formula [3]:

$$
b=\frac{3}{4} \eta+\frac{\gamma-1}{C_{P}} \chi+\eta^{\prime}
$$

where $\eta, \eta^{\prime}-$ shear and bulk viscosity; $\gamma=$ $=\frac{K}{P}+\frac{1}{R / P}-$ bulk modulus of elasticity of the liquid at atmospheric pressure within its internal pressure; $C_{p}$ - heat capacity at constant pressure; $\chi$ - heat conduction coefficient; $\varepsilon$ - dissipation of energy in the medium is given by:

$$
\varepsilon=\frac{V^{3}}{\lambda_{f}}
$$

where $V$ - liquid velocity in the acoustic flow, which can be defined by the formula (12); $\lambda_{f}$ - flow scale; $\rho$ - liquid density.

The rate of dissolution of the granules in terms of acoustic turbulence flow for size $d_{g r} \gg \lambda_{0}$ and $d_{g r} \ll \lambda_{0}$ without cavitation is determined by formulas [18]:

$$
\begin{aligned}
& d_{\text {lim }} \gg \lambda_{0} \frac{d m}{d \tau}=\frac{\sqrt{r} S \cdot U_{\max } \Delta C}{\operatorname{Pr}^{* 3 / 2}}, \\
& d_{\text {lim }} \ll \lambda_{0} \frac{d m}{d \tau}=8 \Delta C \sqrt[3]{D^{2} d_{g r}^{4} U},
\end{aligned}
$$

where $m$ - the mass of granule; $r$ - resistance coefficient; $S=\pi R^{2}-$ cross-sectional area of the granule; $\operatorname{Pr}^{*}=v / D-$ diffusion Prandtl number; $D$ - diffusion coefficient; $d_{g r}=2 R-$ diameter of granule; $\Delta C=\left(c-c^{*}\right)-$ difference of concentrations; $U_{\max }$ and $U$ - velocity and relative velocity of the liquid relative to the granule:

$$
\begin{aligned}
& U_{\max }=\left(\frac{\rho_{s}-\rho}{\rho}\right)^{2 / 3}\left(\frac{\varepsilon d_{g r}}{\rho_{s} r}\right)^{1 / 3}, \\
& U=2 / 3 \sqrt{3}\left[\left(\rho_{s}-\rho\right) / \rho\right] d_{g r}^{2}\left(\frac{\varepsilon_{0}^{3}}{v^{5}}\right)^{\frac{1}{4}} .
\end{aligned}
$$

Dissolution rate of the granules in cavitation conditions accompanying the laminar stationary flow of granules is determined by the formula [11]: 


$$
\frac{d m}{d t}=3,3 \pi^{1 / 3} D^{2 / 3} v^{1 / 3} d_{g r} \Delta C .
$$

Given that volume, cross-sectional area and mass of granule are determined by:

$$
\begin{aligned}
& V_{g r}=\frac{4 \pi R^{3}}{3}, \\
& S_{g r}=\pi R^{2}, \\
& m=\frac{4 \pi R^{3}}{3} \rho_{s} .
\end{aligned}
$$

Equation (19)-(21) will be written as:

$$
\begin{aligned}
& R \gg\left(\frac{\lambda_{0}}{2}\right) \frac{d R}{d \tau}=\frac{\sqrt{r} \cdot U_{\max } \Delta C}{4 \rho_{s} \operatorname{Pr}^{* 3 / 2}}, \\
& R \ll\left(\frac{\lambda_{0}}{2}\right) \frac{d R}{d \tau}=\frac{4 \Delta C}{\pi R \rho_{s}} \sqrt[3]{2 D^{2} R U}, \\
& \frac{d R}{d \tau}=1,65\left(\frac{D}{\pi}\right)^{2 / 3} \frac{v^{1 / 3}}{R \rho_{s}} \Delta C .
\end{aligned}
$$

These equations can be used for theoretical research of dissolution processes of solids in liquid solvents under action of ultrasound and for design of new equipment for the preparation of solutions.

Equations (25)-(27) determine a change of granule radius during the dissolution that it is determined by the time and the conditions of the process. Because radius is a variable, the selection of equation for the calculation will be determined by the ratio of the radius and maximum turbulence scale $\lambda_{0}$. This will get more accurate results, and choose the initial granule size to significantly reduce the time of dissolution, thus improving productivity of equipment.

The results of experimental studies, methods of processing, comparison of research results with calculated results by equations (25)-(27) will be presented in subsequent studies of the authors.

\section{SWOT analysis of research results}

Strengths. Analysis of research results of mass transfer processes in terms of ultrasound treatment reveals the nature of the phenomenon under study, and shows that equalization of solute concentration in the liquid is intensified under the influence of acoustic flows and microflows. In the boundary layer, near granules, reduction of mass transfer resistance is due to the occurrence of cavitation bubbles. This phenomenon allows to intensify the dissolution process of solids in liquid solvents and reduce the time of dissolution of solid substances in liquid solvents under the action of ultrasonic irradiation.

Weaknesses. Multi-aggregate mechanical system under action of ultrasonic irradiation creates a complex and ambiguous understanding of the dissolution process of solids in liquid solvents and at the same time there is a steady increase in temperature.

Opportunities. The mathematical model will enable use in conducting numerous studies as a basis of equipment calculation methods for dissolution process of granular material.

Threats. Properties of ultrasonic influence on liquid were effectively studied since the 90 s of last century by German specialists (Hielscher - Ultraschall - Technologie) [19], namely, for purification, such as from oil. The specialists of «Alexandra-Plus», LTD (Russia) is studying the possibility of using ultrasound equipment for a wide range of applications in the food industry and medicine, and nuclear power engineering, metallurgy and municipal services. U-sonic company (Russia) supplies the Russian market by ultrasound equipment for the pharmaceutical and food industries from 2002.

Due to the fact that the direction of research is narrow, the above-mentioned foreign companies make Ukrainian enterprises uncompetitive.

\section{Conclusions}

1. Dissolution process of solids in liquid solvents under action of ultrasound is analyzed. The analysis shows that intensification is influenced by acoustic flows and microflows and by the occurrence of cavitation bubbles. It is found that dissolution process under action of cavitation with decreasing particle diameter is most intensive.

2. It is established that dissolution rate of solid granules in water in the face of acoustic flows depends on the ratio of the granules and the maximum turbulence scale.

3. It is established that dissolution rate of the granules in cavitation conditions accompanying the laminar stationary flow of granules depends on the diffusion coefficient and viscosity.

Research results will be useful for calculation of equipment for manufacturing operations of preparation of solutions in the biotechnological and pharmaceutical industries.

\section{References}

1. Berezin, B. D. Osnovnye zakony himii [Text]: Textbook / B. D. Berezin, G. A. Krestov. - Moscow: Nauka, 1999. - 95 p.

2. Zdanovskii, A. B. Kinetika rastvoreniia prirodnyh solei v usloviiah vynuzhdennoi konvektsii [Text] / A. B. Zdanovskii; by ed. V. V. Viazov // Trudy Vsesoiuznogo nauchno-issledovatel'skogo instituta galurgii. - Leningrad: Goshimizdat, 1956. - Vol. 33. - 219 p.

3. Nikiforov, M. Yu. Rastvory neelektrolitov v zhidkostiah [Text] Monograph / M. Yu. Nikiforov, G. A. Alper, V. A. Durov, V. P. Korolev, A. I. Viugin, G. A. Krestov, V. V. Miasoedova, A. G. Krestov. - Moscow: Nauka, 1989. - 263 p.

4. Lebedev, N. M. Issledovanie sovmestnogo vliianiia ul'trafioletovogo oblucheniia (UFO) i ul'trazvukovoi obrabotki (UZO) na dinamiku okislitel'no-vosstanovitel'nyh protsessov v vodnoi srede [Text] N. M. Lebedev, M. A. Tihonov, O. V. Kazukov, O. Yu. Lebedev, Z. V. Kireeva, O. B. Kuznetsova // Materialy VI Kongressa obogatitelei stran SNG, 28-30 marta 2007 g. - LLC «AleksandraPlius», 2007. - Vol. II. - P. 234-237.

5. Mel'nick, V. M. Masoobmin i aeratsiia v bioreaktorakh [Text] Monograph / V. M. Mel'nick, M. S. Trivailo, V. V Karachun. Kyiv: Korniichuk, 2009. - 96 p.

6. Kudriashov, V. L. Effektivnost' i problemy primeneniia ul'trazvuka $\mathrm{v}$ tehnologicheskih liniiah pishchevoi promyshlennosti [Text] V. L. Kudriashov, A. N. Siverskaia, N. M. Lebedev, K. V. Naumov, V. E. Lyzhin, E. S. Pavlova, N. S. Pogorzhelskaia, N. V. Malikova // Trudy nauchno-prakticheskoi konferentsii «Tehnologicheskie aspekty kompleksnoi pererabotki sel'skohoziaistvennogo syr'ia pri proizvodstve ekologicheski bezopasnyh pishchevyh produktov obshchego i spetsial'nogo naznacheniia», 11-14 sentiabria 2002 g. - Uglich: Rossel'hozakademiia, 2002. - P. 249-252. 
7. Ponomarev, V. D. Ekstragirovanie lekarstvennogo syr'ia [Text] / V. D. Ponomarev. - Moscow: Meditsina, 1976. - 202 p.

8. Complex module for treating liquid medium in stream [Electronic resource]: Patent RU 2403209 C2 / Lebedev N. M., Kazukov O. V., Koniahin A. V.; assignee: LLC «Aleksandra-Plius». № 2008115030; filed 16.04.2008; published 10.11.2010. Available at: \www/URL: https://patents.google.com/patent/ RU2403209C2/ru

9. Durbha, K. S. Quantification of surface area and intrinsic mass transfer coefficient for ultrasound-assisted dissolution process of a sparingly soluble solid dispersed in aqueous solutions [Text] / K. S. Durbha, K. Aravamudan // Ultrasonics Sonochemistry. - 2012. - Vol. 19, № 3. - P. 509-521. doi:10.1016/ j.ultsonch.2011.09.008

10. Pereira, S. V. Ultrasound influence on the solubility of solid dispersions prepared for a poorly soluble drug [Text] S. V. Pereira, F. B. Colombo, L. A. P. de Freitas // Ultrasonics Sonochemistry. - 2016. - Vol. 29. - P. 461-469. doi:10.1016/ j.ultsonch.2015.10.022

11. Grenman, H. Enhancement of solid dissolution by ultrasound [Text] / H. Grenman, E. Murzina, M. Ronnholm, K. Eranen, J.-P. Mikkola, M. Lahtinen, T. Salmi, D. Yu. Murzin // Chemical Engineering and Processing: Process Intensification. - 2007. Vol. 46, № 9. - P. 862-869. doi:10.1016/j.cep.2007.05.013

12. Inigo, A. C. Dissolution of salts crystallised in building materials using ultrasound: an alternative to NORMAL (1983) standard methodology [Text] / A. C. Inigo, R. Alonso, S. Vicente-Tavera // Ultrasonics Sonochemistry. - 2001. - Vol. 8, № 2. - P. 127-130. doi:10.1016/s1350-4177(00)00062-6

13. Lan, W. Ultrasound-assisted dissolution of cellulose in ionic liquid [Text] / W. Lan, C.-F. Liu, F.-X. Yue, R.-C. Sun, J. F. Kennedy // Carbohydrate Polymers. - 2011. - Vol. 86, № 2. P. 672-677. doi:10.1016/j.carbpol.2011.05.013

14. Sicaire, A.-G. Ultrasound induced green solvent extraction of oil from oleaginous seeds [Text] / A.-G. Sicaire, M. A. Vian, F. Fine, P. Carre, S. Tostain, F. Chemat // Ultrasonics Sonochemistry. - 2016. - Vol. 31. - P. 319-329. doi:10.1016/ j.ultsonch.2016.01.011

15. Karimi, M. Ultrasound irradiation in the production of ethanol from biomass [Text] / M. Karimi, B. Jenkins, P. Stroeve // Renewable and Sustainable Energy Reviews. - 2014. - Vol. 40. P. 400-421. doi:10.1016/j.rser.2014.07.151

16. Akselrud, G. A. Massoobmen v sisteme tverdoe telo-zhidkost' [Text] / G. A. Akselrud. - Lviv: Lviv University Publishing, 1970. - $188 \mathrm{p}$.
17. Shutilov, V. A. Osnovy fiziki ul'trazvuka [Text]: Textbook / V. A. Shutilov. - Leningrad: Leningrad University Publishing, 1980. - $280 \mathrm{p}$

18. Novitskii, B. G. Primenenie akusticheskih kolebanii v himikotehnologicheskih protsessah [Text] / B. G. Novitskii. - Moscow: Himiia, 1983. - 192 p.

19. Ultraschall für Öl, Gas und erneuerbare Kraftstoffe [Electronic resource] // Hielscher - Ultrasound Technology. - Available at: \www/URL: https://www.hielscher.com/de/oil_gas_01.htm

\section{ЛОСТРОЕНИЕ МАТЕМАТИЧЕСКОЙ МОДЕЛИ ПРОЦЕССА РАСТВОРЕНИЯ ТВЕРДЫХ ВЕЩЕСТВ ПОД ДЕЙСТВИЕМ УЛЬТРАЗВУКА}

Представлены результаты полунатурных испытаний при растворении твердых веществ в жидких растворителях в условиях действия ультразвука в жидкой среде и предложена математическая модель процесса. Выявлено появление знакопеременного давления, течения, кавитация, что способствуют интенсификации процессов массопереноса. Доказано, что скорость растворения твердых веществ зависит от интенсивности, частоты и амплитуды ультразвуковых колебаний.

Ключевые слова: растворение, ультразвук, диффузия, массоперенос, интенсификация, кавитация, пузырьки, твердая гранула, скорость.

Mel'nick Viktorij, Doctor of Technical Sciences, Professor, Head of Department of Biotechnics and Engineering, National Technical University of Ukraine «Igor Sikorsky Kyiv Polytechnic Institute», Ukraine,e-mail:vmm71@i.ua, ORCID: http://orcid.org/0000-00020004-7218

Ruzhinska Ludmila, PhD, Associate Professor, Department of Biotechnics and Engineering, National Technical University of Ukraine «Igor Sikorsky Kyiv Polytechnic Institute»,Ukraine, e-mail:ruzhli@ukr.net, ORCID: http://orcid.org/0000-0003-1223-7649

Forostyanko Vitalij, Department of Biotechnics and Engineering, National Technical University of Ukraine «Igor Sikorsky Kyiv Polytechnic Institute», Ukraine, e-mail: forostyanko1993@mail.ru, ORCID: http://orcid.org/0000-0003-4276-8213 